\title{
Bread as dignity: The Constitution and the Consumer Protection Act 68 of 2008
}

\author{
Andrea Bauling* \\ $B A L L B L L M$ \\ Lecturer, Department of Jurisprudence, University of South Africa
}

\section{Annelize Nagtegaal}

$L L B$ LLM

Lecturer, Department of Private Law, University of Pretoria

\section{OPSOMMING}

Die Grondwet, verbruikersbeskerming en brood as menswaardigheid

Die belang van die onderlinge verband tussen mense- en verbruikersregte, (her)verdelende billikheid, verbruikersbeskerming en die kontraktereg moet vooropgestel word. Die reg op gelykheid en menswaardigheid het die mees direkte invloed op die kontraktereg. Die kontrak kan potensieel as ' $n$ instrument gebruik word waarmee armoede gedupliseer word. Die rol wat verbruikersbeskerming wetgewing speel in die proses om die verbruiker van die ekonomiese gevolge van onregverdige verbruikersoor-eenkomste te beskerm, moet geevalueer word in oorleg met die grondwetlikvoorgeskrewe plig om op ' $\mathrm{n}$ volgehoue basis die regverdigheid en regmatigheid van die kontraktereg te verseker. Dit is uiters belangrik om die werklike bedingingstand van die partye te identifiseer, aangesien hierdie inligting noodsaaklik is om te bepaal of die ooreenkoms so aangegaan is om die voldoening van sosiale geregtigheid te bewerkstellig. Die Wet op Verbruikersbeskerming ${ }^{1}$ stel regverdigde metodes daar waarmee kontrak-vryheid ingeperk word om sodoende die ekonomies grensgeval-verbruiker te beskerm. Die ideaal van die etiese kontrak kan verdere leiding in hierdie verband verskaf. Die hoofdoel van die Wet, om die mees kwesbare lede van die samelewing te beskerm wanneer hul verbuikersooreenkomste aangaan, moet by elke moontlike geleentheid nagestreef word. Die impak van die uiters ongelyke bedingingstand van lede van die Suid-Afrikaanse samelewing kan nie langer afgemaak word indien ' $n$ billike en substantief-gelyke kontraktuele speelveld vereis word nie. Die vermoë om brood, een van die mees basiese verbruikersgoedere, te koop is een mate van waardigheid. Die rol van die reg in die SuidAfrikaanse transformerende projek kan nie afgemaak word nie. Die strewe na ' $n$ kontraktuele Utopia kan potensieel, al is dit in ' $n$ mindere mate,

* This article is based on research undertaken for my LLM dissertation at the University of Pretoria. A version thereof was also presented at the University of Pretoria's International Consumer Law Conference on 26 September 2014. I would like to thank my supervisor, Mrs Nagtegaal, as well as the reviewers of this article, for their valuable comments and suggestions. Any errors or omissions remain my own.

1 'n Nie-amptelike vertaling van die Consumer Protection Act 68 of 2008 is beskikbaar by http://www.vra.co.za/vorms/WET \% 20OP \% 20VERBRUIKERS BESKERMING \% 20(No \% 2068\% 20van \% 202008) \% 20Afr.pdf

How to cite: Bauling \& Nagtegaal 'The Constitution, consumer protection and bread as dignity' 
bydra tot die proses om armoede uit te roei en gelykheid in die samelewing daar te stel. Alle geleenthede moet benut word in die soeke na maniere om armoede aan te spreek. Die hoop is dat die Wet op Verbruikers-berskerming die era van die etiese kontrak sal inlei.

\section{Introduction}

Since South African law comprises a single legal system, ${ }^{2}$ guided by the Constitution, ${ }^{3}$ constitutional values and the rights enshrined in the Bill of Rights must inform the law of contract. The rights to equality and human dignity are those which have the most direct influence on contract law. ${ }^{4}$ If critically analysed from a transformative constitutional perspective, the law of contract has not yet embraced the spirit and purport of the constitutional project. ${ }^{5}$ It has also been argued that the courts have in fact been achieving the exact opposite.

Davis states that the highest courts of South Africa have not yet embraced the distributive potential of the law of contract and, at present, it benefits and protects some legal subjects while subordinating others. ${ }^{6}$ He further welcomes the changes to the law of contract that the Consumer Protection Act 68 of 2008 (CPA or the Act) appears to implement, but warns that:

For the jurisprudence that emerges from the Consumer Protection Act to be coherent, the courts will no longer be able to eschew an interrogation of the ground rules upon which the contractual arrangement has been ultimately fashioned ... Inequality of bargaining power and the consequences thereof lie at the heart of the considerations of which the court is required to take into account in terms of [the Act]. ${ }^{7}$

This clearly illustrates the relationship between rights, distributive justice, the law of contract, and more specifically, consumer agreements. ${ }^{8}$ The desired and required societal change demanded by the fall of apartheid can only be achieved by altering the current outlook on wealth

2 Pharmaceutical Manufacturers Association of South Africa: In re Ex Parte President of the Republic of South Africa 2000 (2) SA 674 (CC) par 44.

$3 \mathrm{~S} 2$ of the Constitution of the Republic of South Africa, 1996 (the Constitution).

4 Barnard AJ A critical legal argument for contractual justice in the South African law of contract (LLD dissertation 2006 UP) 229.

5 Davis 'Developing the common law of contract in the light of poverty and illiteracy: The challenge of the Constitution' 2011 Stell LR 845 847; Davis \& Klare 'Transformative constitutionalism and the common and customary law' 2010 SAJHR 403 415. See also Bhana ('The horizontal application of the Bill of Rights: A reconciliation of sections 8 and 39 of the Constitution' 2013 SAJHR 351 375) and Moseneke ('Transformative constitutionalism: Its implications for the law of contract' 2009 Stell LR 3 13) who refer to the "constitutionalisation" of the South African private law and common law, respectively. For a more detailed discussion see par 22 infra.

6 Davis 2011 Stell LR 845846.

7 Idem 861

8 As defined in s 1 sv "consumer agreement". 
distribution. ${ }^{9}$ Only once this shift is achieved, can an attempt be made to rectify the socio-economic injustices caused by such a systemically and fundamentally unjust system, since "political change would scarcely enjoy legitimacy unless it could provide real, visible benefits for poor and marginalised members and sectors of society" ${ }^{10}$ The manner in which the common law of contract is currently interpreted and applied, does very little to better the position of the most impoverished in this country.

Traditional contract theory is built on the assumption that the parties to the contract negotiated the terms of the contract, reached consensus on each term and occupied equal bargaining positions during the negotiations. ${ }^{11}$ This is unfortunately not observed in practice; traders and enterprises make use of standard form contracts that are slanted in their favour and not open to negotiation by the consumer. ${ }^{12}$ Furthermore, many consumer contracts are concluded out of necessity, as life sustaining products are also purchased by means of consumer contracts. In light of this the common law remedies to address unfair contracts and contractual terms were considered insufficient. ${ }^{13}$

The CPA, as social justice legislation, has as aim the transformative constitutional aspiration to kindle and drive socio-economic change in the impoverished South African society. Law's political element implies a process of implementing law to achieve political aims. Inducing drastic socio-economic transformation in the community as a whole is also one of the most important aims of the South African developmental state. Legislation could and should thus be employed in this regard.

The CPA highlights the position of the vulnerable party in a sales agreement, as well as how this vulnerability is directly related to the socio-economic position the vulnerable person fills in the community. ${ }^{14}$ In line with its purpose, the Act implicitly addresses the notion of the poor as vulnerable, and the protection it aims to provide the vulnerable in an attempt to address poverty, is of importance and should be evaluated and approached from within the constitutional framework. In order to achieve its transformative goal the Act provides additional objectives: creating and supporting a fair, accessible, efficient and

9 Van der Walt 'Legal History, Legal Culture and Transformation in a Constitutional Democracy’ 2006 Fundamina 12.

10 Ibid.

11 Woker 'Why the need for consumer legislation? A look at some of the reasons behind the promulgation of the National Credit Act and the Consumer Protection Act' 2010 Obiter 217231.

12 Sharrock 'Judicial control of unfair contract terms: The implications of Consumer Protection Act' 2010 SA Merc LJ 295296.

13 Ibid.

$14 \mathrm{~S} 3(1)(b)$ describes one chief aim of the Act as protecting vulnerable members of society: low-income persons and communities; individuals and communities how live in isolated or poorly populated areas; minors, seniors and similarly vulnerable individuals; or those who are hindered by poor literacy or language skills, or impaired vision, to read or understand advertisements, agreements or other visual representations. 
sustainable consumer market; ${ }^{15}$ promoting fair business practices; ${ }^{16}$ and shielding consumers from suppliers' unfair trade practices and conduct. ${ }^{17}$

The CPA does not apply to all commercial transactions and the common law is consequently the reigning law in a great number of instances. ${ }^{18}$ Therefore, this article will evaluate the protection granted to the consumer in terms of the CPA, as well as the common law. ${ }^{19}$ However, the common law cannot be viewed as independent from the Constitution. The role of the Constitution in the South African developmental state and the role of contractual justice and paternalism will be scrutinised. Transformative constitutionalism and law itself will be assessed in terms of its potential to truly improve the socio-economic situation of the vulnerable and impoverished consumer. The ethical contract and the role of the CPA as a vehicle for contractual justice will be discussed. This article is written with the contract of purchase and sale and consumer agreements in terms of which goods are purchased, as its focus. ${ }^{20}$

\section{The Common Law and the Constitution}

The lack of constitutional development in the field of contract law must be regarded with concern, as it results from the courts' adherence to liberal interpretations and applications of the law which ultimately favour autonomy above paternalism. It has been said that the survival of the "splendid" 21 ancient Roman and the subsequent Roman-Dutch legal principles is miraculous ${ }^{22}$ and can be attributed to the fact that South African courts have been able to efficiently and successfully adapt these ancient rules to the imperatives of modern life. ${ }^{23}$ This view is however not held universally. It may be argued that painstakingly slow and incremental development of a truly unfair area of the common law has

$15 \mathrm{~S} 3(1)(\mathrm{a})$

16 S $3(1)(\mathrm{c})$

17 S 3(1)(d)

18 S 5(1)(a) of the CPA provides the scope of the application of the Act while $\mathrm{S}$ $5(2)$ lists the transactions exempt from the provisions of the Act.

$19 \mathrm{~S} 2(10)$ of the CPA states that the consumer is protected by the consumer rights as contained in the Act, as well as the common law rights available to her in terms of the common law.

20 Although the National Credit Act 34 of 2005 (National Credit Act) has great potential to address poverty as a social ill by protecting poor individuals from credit agreements, which will detrimentally affect their financial position, an analysis of the effect of the National Credit Act on poverty in South Africa falls beyond the ambit of this article.

21 Ex parte De Winnaar 1959 (1) SA 837 (N) 839.

22 Van Niekerk 'The endurance of the Roman tradition in South African law' 2011 Stud Iuris 120.

23 Otto 'Verborge gebreke, voetstootverkope, die Consumer Protection Act en die National Credit Act: Ius antiquum, ius vetus et ius futurum; aut ius civile, ius commune et ius futurum' 2011 THRHR 525527. 
resulted in the legislature's much-needed intervention in the form of the National Credit Act and CPA.

Van der Walt proposes a methodology to be used when the common law, applicable to an area of private law, is developed in order to achieve transformative ideals. $^{24} \mathrm{He}$ also criticises the idea that the existing "flexible" common law will evolve enough over time to bring about a sufficiently transformed legal system:

[T] he notion that development of the law has to be accomplished through incremental, interstitial developments of the common law doctrine ... is problematic in view of the necessity of meaningful and significant transformation ... [T] he incremental judicial process of interstitial development may well be too slow and protracted because it is driven by the logic of doctrinal development and not by the need for change. ${ }^{25}$

\section{Poverty and the South African Developmental State}

The notion of referring to the developmental state has become a fashionable manner to address the exploration of developmental challenges experienced by nation states. ${ }^{26}$ The developmental state is identified as one where governing forces initiate a spirited drive towards economic growth and implements national resources towards a developmental goal. ${ }^{27}$ In South Africa, this goal has been identified as broad-based economic development. ${ }^{28}$

The South African government has the duty to address the lived reality of the poor and vulnerable. ${ }^{29}$ Socio-economic rights are constitutionally enshrined and the state must take "reasonable legislative and other measures, within its available resources, to achieve the progressive

24 Van der Walt 'Development of the Common Law of Servitude' 2013 SALJ 722-756. Van der Walt's research relates to the development of the common law of property and servitudes in particular, but the methodology proposed is expounded in a manner which invites jurists to tackle all research regarding the development of the common law in the proposed fashion. He contends that any attempt to endorse developments of the common law, should start with a detailed account of the historical development of the common law in question, followed by a clear exposition as to why the existing common law is incongruent with the Constitution (738). Davis ('Where is the map to guide common-law development?' 2014 Stell LR 4 12) argues that the next step requires an investigation into the fundamental values of the Constitution, before an attempt can be made to align the common law in question with the Constitution.

25 Van der Walt 2006 Fundamina 19 (own emphasis).

26 Machete 'Developmental state: Implications for rural development in South Africa' in Turok (ed) Wealth doesn't trickle down - The case for the developmental state in South Africa (2008) 121.

27 Levin 'Public service capacity and organisation in the South African developmental state' in Turok supra n 26 at 50.

28 Turok 'What is distinctive about a South African developmental state?' in Turok (ed) supra n 26 at 160.

29 Levin in Turok (ed) supra n 26 at 50. 
realisation of these rights" ${ }^{30}$ Such socio-economic development should involve participatory planning to realise practical redistribution in order to address poverty. ${ }^{31}$ It can be argued that the promulgation of consumer legislation is an attempt to address poverty in South Africa, albeit in an indirect manner. By protecting poor and vulnerable members of society from "abuse or exploitation in the marketplace", ${ }^{22}$ the state is attempting to address poverty by means of legislative measures. Consumer legislation, as a weapon against poverty, does not put money or property in the hands of the poor, but aims to minimise the possibility of their manipulation by more powerful role players in the consumer market.

It is practically impossible to eradicate poverty in developing nations without implementing elements of the developmental state. ${ }^{33}$ The gross inequalities so blatantly evident in our society cannot be remedied through the operation of the capitalist market: ${ }^{34}$ "We cannot depend on 'trickle down' or 'ladders up' to create a more just and equal society", ${ }^{35}$ because "[w]ealth doesn't trickle down". ${ }^{36}$ Jahed and Kimathi argue that development ${ }^{37}$ cannot be achieved without intervention by the state and that legislation provides a "perfectly legitimate" 38 instrument with which to achieve such intervention. ${ }^{39}$

Decisions related to the management of the economy should be made with the collective society in mind, since the economy is in essence socially owned and new mechanisms for sustaining politico-economic democracy is thus necessitated. ${ }^{40}$ Continuous intervention is required to bolster the development and transformation of our society, and accordingly the traditional, conservative interpretation and application of the law of contract should be ceased. ${ }^{41}$ South Africa's conservative legal culture, as perpetuated by the courts, is perpetuating poverty and a skewed vision of the distribution of wealth, power and resources in our society.

$30 \mathrm{~S} 27(2)$ of the Constitution.

31 Levin in Turok (ed) supra n 26 at 52.

32 Preamble of the CPA.

33 Levin in Turok (ed) supra n 26 at 51.

34 Idem 54.

35 Turok in Turok (ed) supra n 26 at 159.

36 Ibid

37 Regarding the importance of development and the upliftment of communities, see Church 'Sustainable Development and the Culture of uBuntu’ 2012 De Jure 511.

38 Graham 'Socio-economic rights: cornerstone or capstone of democracy?' in Jones \& Stokke (eds) Democratising Development - The politics of socioeconomic rights in South Africa (2005) 284.

39 Jahed \& Kimathi 'The economics of developmental states' in Turok supra $n$ 26 at 97; Graham in Jones \& Stokke (eds) supra n 38 at 284.

40 Szentes The Transformation of the World Economy (1988) 91.

41 Hawthorne 'Distribution of wealth, the dependency theory and the law of contract' 2006 THRHR 48 


\section{The Impetus for Transforming the Law of Contract in line with the Constitution}

Directly opposed to the position defending the efficacy and superiority of the Roman-Dutch legal principles present in our common law, are the arguments put forward by transformative constitutionalists. These scholars believe that the common law, as rooted in Roman-Dutch and English legal principles, has, to date, not yet transformed enough to truly embrace the constitutional values of dignity, equality and freedom. ${ }^{42}$

The perception that the Constitution should serve as the inspiration for reconfiguring the common law rules which govern all economic activity, provides exciting possibilities and challenges. However, to date the courts have only referred to constitutional values in passing and then the focus of their judgments shifts to "the "real' law of contract". 43 The freedom of contract debacle proves this argument impeccably.

\section{A Prime Example}

The foundation of the South African common law of contract has been identified as freedom of contract, or "the idol that is pacta servanda sunt". " Freedom of contract is based on the presumption that the parties to a contract occupy an equal bargaining position. ${ }^{45}$ This presumption also serves as the justification for the enforcement of contracts. More often than not, the vastly disparate socio-economic realities of the parties in question have a direct influence on their bargaining power; freedom of contract and formal equality ${ }^{46}$ perpetuate injustice and social inequalities which often results in the domination of one contracting party over the other. ${ }^{47}$ Equal bargaining power will never be a reality if one party contracts out of necessity and in order to survive. ${ }^{48}$ This is especially true in instances where basic consumer contracts and credit agreements are concluded. Consumer and sales agreements are often concluded without the vulnerable party really understanding what the

42 Klare 'Legal culture an transformative constitutionalism' 1998 SAJHR 146; Davis 2011 Stell RL 845-864; Van der Walt 2006 Fundamina 1; Van Marle 'Transformative constitutionalism as/and critique' 2009 Stell LR 286. See also Hawthorne 2006 THRHR 48-49.

43 Davis 2011 Stell LR 845 847; Davis \& Klare 2010 SAJHR 403415.

44 Ibid. Barnard AJ 241; Hawthorne 2006 THRHR 48 53. For an exposition of freedom of contract see Hawthorne 'The principle of equality in the law of contract' 1995 THRHR 157 163, where she described the concept as having four distinct meanings.

45 Barnard AJ 213; Hawthorne 2006 THRHR 4853.

46 Absolute equality before the law (Hawthorne 1995 THRHR 157 159).

47 Idem 163; Hawthorne 2006 THRHR 48 53; Barnard AJ 248; Lucy 'Contract as a Mechanism of Distributive Justice' 1989 Oxford J. Legal Stud. 132146.

48 Hawthorne 1995 THRHR 157 163; Hawthorne 2006 THRHR 48 53-54 \& 61. Also see Davis 2011 Stell LR 845862 referring to Hale 'Bargaining, Duress and Economic Liberty' 1943 Columbia LR 603625. 
agreement entails, which reinforce the view that "[f]ormal equality before the law is an engine of oppression". 49

Pieterse argues that equality must be understood as being in touch with the societal context of parties: Attaining substantive (true) equality requires engagement with the disregard for the reality of the vulnerable. ${ }^{50}$ This reality is that the most disadvantaged individuals in our society never attain the economic status which empowers them to take part in market transactions as true equals with equal bargaining power. ${ }^{51}$ Because of this, freedom of contract provides no freedom at all.

The freedom to contract may be limited by public policy or the boni mores. ${ }^{52}$ It has also been argued that public policy is closely related to good faith in the law of contract. ${ }^{53}$ But interestingly an inferred contradiction exists between the sanctity of contract (autonomy) and good faith (constraint), to the point that these concepts seem irreconcilable. ${ }^{54}$ The contemporary common law is haunted by the continuous struggle between autonomous and paternalistic approaches in an attempt to achieve a measure of justice for all legal subjects. Barnard argues that the law in its present form does more to hinder the accomplishment of a sense of balance between autonomy and paternalism, than to achieve it. ${ }^{55}$

The freedom of contract cases ${ }^{56}$ epitomise the courts' unrelenting adherence to the tradition and legal analysis associated with the common law and the resultant lack of transformation of contract law. ${ }^{57}$ Davis and Klare argue that, although not blatantly obvious, these cases illustrate an adherence to apartheid-era morality, racial discrimination and conservative thinking about the law. ${ }^{58}$ They are stunned by the courts' blatant disregard for the social contexts relevant to the cases, and list this as one of the central difficulties with these judgments. ${ }^{59}$ Directly related to this, is the disregard for the disparate bargaining power of parties to the contracts in question. ${ }^{60}$

49 Hawthorne 1995 THRHR 157 163. In this regard also see Davis 2011 Stell LR 845 854; Kok 'Is law able to transform society?' 2010 SALJ 5968.

50 Pieterse 'What do we mean when we talk about transformative constitutionalism?' 2006 SAPR/PL 155160.

51 Hawthorne 2006 THRHR 48 61-62.

52 Hutchison \& Du Bois 'Contracts in general' in Du Bois (eds) Wille's Principles of South African Law (2007) 737, as referred to by Davis 2011 Stell LR 845 847; Barkhuizen v Napier 20077 BCLR (CC) par 14. The Constitution has been described as a "repository of the boni mores" (Davis 2014 Stell LR 3 14).

53 Davis 2011 Stell LR 845847 discussing Hutchison \& Du Bois ibid.

54 Barnard AJ 229; Davis \& Klare 2010 SAJHR 471.

55 Barnard AJ 220

56 Brisley v Drotsky 20024 SA 1 (SCA); Afrox Healthcare v Strydom 20026 SA 21 (SCA) and Barkhuizen $v$ Napier 2007 (5) SA 323 (CC).

57 Davis \& Klare 2010 SAJHR 403468.

58 Ibid.

59 Idem 480

60 Ibid. 
Paternalism refers to a reigning measure of control which influences individuals' ability to act autonomously, thereby protecting them from acting or deciding in a manner which will attenuate their general wellbeing. ${ }^{61}$ Autonomy, on the other hand is equated to the liberal ideal of "the "good life"." 62 Autonomy allows freedom of contract to reign unchallenged. Paternalism sanctions the notion that the state's judgment (often superimposed through the work of the legislature) supersedes and replaces the individual's predilections. ${ }^{63}$

The National Credit Act and the CPA are examples of paternalistic legislation which limits freedom of contract with the intention of protecting the interests of the consumer. The CPA expressly dictates that the purpose of the Act is to protect the most vulnerable of consumers from the adverse consequences of unfair consumer agreements. ${ }^{64}$ The socio-economic reality of these vulnerable consumers thus becomes important.

\section{Redistribution}

In an attempt to attain the truly egalitarian society where substantive equality is the order of the day, legal rules should regulate the manner in which contractual power is exerted during the conclusion of (consumer) agreements, since one of the principal spinoffs of the contract is the division of wealth in a society. ${ }^{65}$ The contact is thus one of the principal tools which may be employed for the distribution of wealth, power and resources in a society and therefore the right to equality ${ }^{66}$ demands that distributive concerns be considered. ${ }^{67}$ The reality of the inequality of resources demands that the actual resources of the parties involved be

61 Hawthorne 1995 THRHR 157168.

62 Davis 2011 Stell LR 845 848. See also Davis \& Klare 2010 SAJHR 403411.

63 Hawthorne 'Making public knowledge, making knowledge public: Information obligations effect truth-in-lending and responsible lending; 2007 SAPR/PL 477479.

64 See $\mathrm{s} 3$ for the purpose of the Act.

65 Hawthorne 2006 THRHR 48 49; Hawthorne 1995 THRHR 157176.

66 As contained in s 9 of the Constitution. The consumer's right to equality in the consumer market is specifically created in terms of Part A of Chapter 2 of the CPA. Here the legislature has expanded on the consumer's right to equality as found in the Bill of Rights, by creating a consumer right with more direct application to marketplace related matters regarding quality. The constitutional right to equality and consumer right to equality in the marketplace both support the drive towards redistribution of wealth and resources.

67 Hawthorne 1995 THRHR 157 176. See also Hawthorne 'Constitution and contract: Human dignity, the theories of capabilities and Existenzgrundlage in South Africa' 2011 Stud Iuris 1. It is not contended that the contract is the only instrument with which to distribute wealth in a society. Lucy (supra $\mathrm{n} 47$ at 147) argues against the contract in favour of taxation as a more efficient way to do so. 
evaluated and considered, ${ }^{68}$ since equality is central to the legal transformative endeavour. ${ }^{69}$

The imperative to redistribute wealth originates from the existence of two unequal groups making up South Africa's society: The opulent haves, and the gut-wrenchingly poor have-nots. ${ }^{70}$ The unequal bargaining power between these unequal groups thus becomes of extreme importance. Cognisance should be taken of how the liberal conceptualisation of the freedom of contract (and the individualism and autonomy it reveres) is actively hindering the (re)distribution of wealth, resources and power in our unequal society. ${ }^{71}$ Surely the contract (of sale) is not the most powerful measure with which to address this vast inequality, but the contract's ability to perpetuate the subordination of those most vulnerable can no longer be ignored.

The paramount importance of the transformative constitutional endeavour to the law of contract and consumer protection is found in the sentiment that our courts are ignoring opportunities to inject equity ${ }^{72}$ into the common law of contract. ${ }^{73}$ Fischer's conception of just law, which should be "morally defensible as tested against the common conviction of the community at large", 74 does not accommodate a system of contract law which does not insist that contracting parties act in good faith.

\section{Bread as Dignity}

Moseneke argues that the fact that the Bill of Rights does not refer to "social justice" by name, does not mean that it is not a constitutionally mandated imperative. ${ }^{75}$ Social justice has various guises and may impact lives and communities in numerous ways. Having one's human dignity respected certainly classifies as an aspect of social justice. Basic goods and conditions essential for survival are also inextricably linked to dignity. The ability to purchase bread has been linked to human dignity by both Mandela and Sachs:

68 Hawthorne 1995 THRHR 157176.

69 Moseneke 'The Fourth Bram Fischer Memorial Lecture - Transformative adjudication' 2002 SAJHR 309316 \& 318; Hawthorne ibid.

70 Sibanda 'Not purpose-made! Transformative constitutionalism, postindependence constitutionalism and the struggle to eradicate poverty' 2011 Stell LR 482497.

71 Davis 2011 Stell LR 845 849-850. See also Hawthorne 2006 THRHR 48 5758.

72 Hawthorne (2006 THRHR 48 58-62) observes that in Haviland Estates (Pty) Ltd v McMaster 19692 SA 312 (A) 336D-G; Lanfear v Du Toit 1943 AD 59; Van der Merwe $v$ Viljoen 19531 SA 60 (A); and Oswanick $v$ African Consolidated Theatres (Pty) Ltd 19673 SA 310 (A) 317E, the courts liken equity to sympathy and therefore, spurn the possibility of applying it completely. In our opinion, Wells $v$ South African Alumenite Co 1927 (AD) 69 could also be added to this list.

73 Idem 62.

74 Moseneke 2002 SAJHR 309311

75 Idem 314 
[D]emocracy itself, cannot survive unless the material needs of the people, the bread and butter issues, are addressed as part of the process of change and as a matter of urgency. It should never be that the anger of the poor should be the finger of accusation pointed at all of us because we failed to respond to the cries of the people for food, for shelter and for the dignity of the individual. ${ }^{76}$

The restoration of dignity for all South Africans accordingly requires the simultaneous creation of material conditions for a dignified life and development of increased respect for the personality and rights of each one of us. Both freedom and bread are necessary for the all-round human being. Instead of undermining each other, they are interrelated and interdependent. ${ }^{77}$

Sachs goes on to state that the fundamental right of having one's human dignity respected becomes the link between freedom and bread. ${ }^{78}$ An essential consumer product therefore, becomes the symbol of dignity and freedom and the consumer and sales agreement thus becomes an instrument with which to further, or hinder, social justice. The circumstances surrounding the conclusion, interpretation and enforcement of these agreements can thus not be ignored.

\section{The Ethical Contract}

With the enactment of the Bill of Rights as contained in the Interim Constitution, freedom of contract was originally understood as being a fundamental human right. ${ }^{79}$ This interpretation does however not hold constitutional muster today. Freedom of contract is associated with (and derived from) political freedom ${ }^{80}$ whereas good faith has its foundation in human dignity. ${ }^{81}$ Barnard argues that freedom, equality and human dignity should be understood and considered concurrently in the context of the constitutional notion of contract. ${ }^{82}$ This conceptualises his idea of the ethical element of contract law. ${ }^{83} \mathrm{He}$ explains the link between human dignity as a form of empowerment ${ }^{84}$ and human dignity embodied in the practice of constraint. ${ }^{85}$ Human dignity relates directly to both the traditional notion of freedom of contract, as an expression of empowerment, as well as good faith in contractual dealings, which is

76 Mandela on poverty, from an address to the joint session of the House of Congress, Washington DC, USA on 1990-06-26 in Hatang \& Venter (eds) Nelson Mandela By Himself (2013) 165.

77 Sachs 'Judicial enforcement of socio-economic rights: the Grootboom case' in Jones \& Stokke supra $\mathrm{n} 38$ at 141.

78 Idem 142

79 Hawthorne 1995 THRHR 157166

80 The traditional link between the right to liberty and freedom of contract stems from the French and American revolutions, as well as the British Industrial Revolution (Hawthorne 2006 THRHR 48 52-53).

81 Barnard AJ 229.

82 Ibid.

83 Idem 229-230.

84 Idem 231-232.

85 Idem 232-234. 
achieved by a measure of constraint. ${ }^{86}$ When looking through the lens of "the ethical element of contract in a constitutional South Africa", Barnard comes to the powerful conclusion that in order to respect the right to human dignity when contracting, the common law right to freedom of contract must be exercised in good faith: 87 "[The] collective achievement of freedom cannot be attained where a claim to freedom violates another's claim to dignity" ${ }^{88} \mathrm{He}$ argues that freedom of contract has a duty or responsibility linked to it and is therefore an ethical freedom. ${ }^{89}$

In striving for the realisation of the consumer's right to dignity, the ethical contract concluded in good faith, becomes an indispensable tool. Transforming South Africa's society on an economic front therefore also requires the application of the Constitution.

\section{The Role of Transformative Constitutionalism}

The Constitution encapsulates the greater South African community's yearning for transformation, while at the same time providing the impetus and means with which to achieve it. 90 In his "celebrated"91 "seminal" $" 22$ article, Klare explains that in a legal system where transformative constitutionalism ${ }^{93}$ is the prerogative, a duty rests on legal scholars to evaluate the role of the Constitution and its inherent power to bring about transformation on a socio-economic front in an impoverished South African society.

The debate regarding the nature and scope of the (direct and/or indirect) horizontal application of the principles of the Bill of Rights has been raging since the promulgation of the Interim Constitution, ${ }^{94}$ and is yet to be resolved. ${ }^{95}$ Consensus has however been reached on the fact that the Constitution and the Bill of Rights apply horizontally between

86 Idem 231-232.

87 Idem 237

88 Idem $237 \& 249$

89 Idem 237

90 Moseneke 2002 SAJHR 309319.

91 Davis 2014 Stell LR 34

92 Sibanda 2011 Stell LR 482487.

93 Klare defines transformative constitutionalism as "a long-term process of constitutional enactment, interpretation, and enforcement committed ... to transforming a country's political and social institutions and power relationships in a democratic, participatory and egalitarian direction. Transformative constitutionalism connotes an enterprise of inducing largescale social change through nonviolent political processes grounded in law" (Klare 1998 SAJHR 146150 (own emphasis))

94 See Hawthorne 1995 THRHR 157 160-162.

95 A series of recently published articles illustrate this point: Bhana 2013 SAJHR 351-375; Roederer 'Remnants of apartheid: The primacy of the spirit, purport and objects of the Bill of Rights for developing the common law and bringing horizontal rights to fruition' 2013 SAJHR 219-250; Friedman 'The South African common law and the Constitution: Revisiting horizontality' 2014 SAJHR 63-88. See also Davis \& Klare 2010 SAJHR 403 415-419. 
private individuals and therefore, examining the law of contract in this light is of paramount importance. This horizontality becomes the reason why we are morally and legally obliged to contract in good faith.

Some however question whether change by means of legislation, and by extension the Constitution, is the appropriate approach to adopt, as well as whether law has the ability to effectively and significantly transform our society to a more equal community.

Sibanda argues that, in spite of all the good attempted in the name of transformative constitutionalism, the liberalistic character and interpretation of the Constitution (resulting from the conservative approach to law ingrained in South African jurists) cannot be avoided. ${ }^{96}$ Transformative constitutionalism is accordingly "ill-suited for achieving the social, economic and political vision it proclaims", 97 since "it promises more than it can actually deliver". 98

Michelman agrees with Sibanda that the South African Constitution is steeped in a classical-liberal legal culture from which it cannot escape. ${ }^{99}$ He views the prevailing political and cultural reality, which adheres to an unwaveringly liberal reading of the law, as the reason that transformative constitutionalism can be seen as "a contradiction in terms". ${ }^{100}$ He thus believes that the Constitution is an inherently flawed transformative tool due to the fact that it was written, and is interpreted, in an inherently conservative manner.

Kok's chief argument is compatible with that of Sibanda: Law has the ability to transform society, but this potential to transform is overestimated. ${ }^{101}$ It is impossible to definitively prove the existence of a sufficiently causal link between changes to the law and the transformation of a society. ${ }^{102}$ Since a legal change is implemented after the fact, as an attempt to address an already existing problem, it "plays no role in influencing human behaviour". 103

In Fourie $v$ Minister of Home Affairs ${ }^{104}$ Cameron JA, as he was then, explained a paradox he believes lies at the heart of South Africa's national project of transformation: "[W]e came from oppression by law, but resolve to seek our future, free from oppression, in regulation by law". ${ }^{105}$ Governments view law as a speedy and cost-effective way to

96 Sibanda 2011 Stell LR 482 485-486.

97 Idem 486.

98 Idem 490 \& 493.

99 Michelman 'Liberal constitutionalism, property rights, and the assault on poverty' 2011 Stell LR $706707 \& 708$.

100 Idem 707.

101 Kok 2010 SALJ $5970 \& 75$.

102 Ibid.

103 Idem 75.

1042005 (3) SA 429 (SCA).

105 Par 7, as quoted by Davis \& Klare 2010 SAJHR 403 503. See also Klare 1998 SAJHR 146169. 
address problems that pop up in a society, in an attempt to change that society and eradicate the problem. ${ }^{106}$ It must be accepted that law may not be the only instrument employed by a state to induce social change. Confirmation of this theory can be found in Lucy's argument that the contract, in essence a voluntary legal exchange, is not the ideal way to achieve distributive justice. ${ }^{107} \mathrm{He}$ believes that taxation is the more appropriate measure with which to attain such justice. ${ }^{108}$

The main critique against transformative constitutionalism is thus that law's power to bring about socio-economic transformation is greatly exaggerated. Along the same vein, Woker questions whether the "lofty aims" of the CPA can truly be realised. ${ }^{109}$ The lived experience of the greater South African society is not one of transformation at the hands of the law. It would, however, be inappropriate to deny that judicial lawmaking can advance social development already in progress. ${ }^{110} \mathrm{We}$, however, do not accept these pessimistic views of the role of the law and constitutional interpretation on face value. The mere fact that law has already assisted in bringing about some change in the South African society, no matter how insufficient such change may seem to some, means that the law can be used to transform the lives of those in our society who rightfully demand it.

Barnard argues for utopian thinking about the law, championing for the value it could potentially hold. In the context of contract law he maintains that " $[\mathrm{u}]$ topian thinking provides the space for contract's reconnection with the ethical in that it openly commits to the ideals of fairness, equity and justice". ${ }^{111}$ He equates true contractual justice to a contractual Utopia. ${ }^{112}$ A societal commitment to contracting in good faith will result in the introduction of the ethical element of contract and this could ultimately result in a measure of contractual justice. ${ }^{113}$

Barnard emphatically and convincingly argues that the fact that irresolvable fundamental contradictions ${ }^{1{ }^{1}}$ exist in the law of contract is the exact reason why the utopian ideal of contractual justice should never be abandoned. ${ }^{115}$ Utopian thinking has the potential to lead to real

106 Kok 2010 SALJ 5983

107 Lucy supra $\mathrm{n} 47$ at 147.

108 Ibid.

109 Woker 2010 Obiter 231

110 Sackville 'Courts and social change' 2005 Fed LR 373390 (own emphasis).

111 Barnard 'Death, mourning and melancholia in post-modern contract - a call for (re)establishing contract's connection with the ethical' 2006 Stell LR 386398.

112 Barnard AJ 241.

113 Ibid.

114 The relationship between freedom of contract and good faith.

115 Barnard AJ 242. 
transformation, ${ }^{116}$ but thinking alone is not enough - immediate action is required: ${ }^{117}$

It is not 'the law' which is responsible for this transformation - it is us who create the law with our human will in the face of our humanity who is inexcusably responsible for transforming it. ${ }^{118}$

Although the law is not the only available transformative apparatus, it can most certainly not be disregarded as such; "law and legal practices can be a foundation of democratic and responsive social transformation"119 and law has the capacity to address injustice. ${ }^{120}$

When transformative constitutionalism and the law of contract are discussed in unison, two crucial truths should be acknowledged. Firstly, cognisance should be taken of the fact that the principles of ubuntu (should) impact the law of contract; and secondly, contract law and consumer protection (should) impact the fight against poverty.

The South African Constitution is informed by a sense of communality and ubuntu. ${ }^{121}$ The minority judgment of the recent decision of the Constitutional Court in Everfresh Market Virginia (Pty) Ltd $v$ Shoprite Checkers (Pty) Ltd, ${ }^{122}$ reiterates the importance of the relationship between ubuntu's focus on the worth of the community and the principle of good faith in contractual dealings.

The crux of this judgment, as handed down by Yacoob J, centres around the fact that the time has arrived for the background (common law) rules of the law of contract to be infused with the principles of good faith and ubuntu in order to make way for a constitutionally conscious contracting epoch. ${ }^{123}$ The Court stated that courts need to start considering good faith in contracts as constitutionally imperative due to its potentially immense impact on the public. ${ }^{124}$ Many ordinary people conclude (consumer) contracts daily and each of these contracts could potentially be performed in a mala fide manner, detrimentally impacting the lives of vulnerable contracting parties. ${ }^{125}$

116 Idem 245

117 Idem 247; "While not sufficient, I do believe that a progressive legal culture is a necessary condition for a long-term success of transformative constitutionalism" (Klare 1998 SAJHR 146 170).

118 Barnard AJ 252

119 Klare 1998 SAJHR 146188 (own emphasis).

120 Pazzanese "My life was going to have to deal with issues of social injustice" - Martha Minow's sense of purpose' in Harvard Gazette, 2014-04-22 (available from http://news.harvard.edu/gazette/story/2014/04/my-life-wasgoing-to-have-to-deal-with-issues-of-social-injustice/ accessed 2014-08-25).

121 Davis \& Klare 2010 SAJHR 403; Klare 1998 SAJHR 146 153; Moseneke 2002 SAJHR 309 313; the Preamble of the Constitution

1222012 (1) SA 256 (CC) (Everfresh case).

123 Idem par 36

124 Idem par 22.

125 Idem par 22. 
The importance of the role of the contract in the daily lives of South Africans cannot be understated. Another essential point raised by the Court is that it would most likely benefit the community as a whole to incorporate the principle of good faith into the law of contract. ${ }^{126}$ The Court makes the link between good faith, the spirit of the Constitution and the principles of ubuntu. It is later confirmed that the principles of ubuntu should inform any decision made on reinstating "the important moral denominator of good faith". ${ }^{27}$ The importance of the unequal bargaining power between poor individuals and financially strong companies is raised and the values ubuntu might bring to the table in this regard are highlighted. ${ }^{128}$ The Court thus confirms Barnard's theory that the introduction of the ethical element of contract is paramount.

What becomes clear is the urgent need to address the reality of poverty in our unequal society, as well as the role which the law of contract might play in this regard. The Constitution imposes a positive duty on the state to "combat poverty and promote social welfare", ${ }^{129}$ as well as providing subjects of the state the ability to live out their constitutional rights by means of self-realisation. ${ }^{130}$ Here self-realisation reminds of the right to dignity and the accompanying ability to purchase bread. The state thus has to endeavour to achieve this goal in any and every manner possible, examples being the enforcement of the Bill of Rights in dealings between citizens themselves, ${ }^{131}$ as well as the promulgation, interpretation and enforcement of legal rules done with this kept in mind. Section 8(2) of the Constitution specifically mandates such action by the state.

Judicial consideration of the plight of the poor who enter into consumer contracts is thus critical, ${ }^{132}$ since the abolition of poverty is a "constitutional imperative". 133 Barnard's argument that the law of contract (and by extension the law of purchase and sale) has an important and significant role to play in the fight against poverty is supported. The transformation envisaged for the law of contract is, firstly, pleading for an interpretation and application of the law which allows for the stretching of the limits that legal scholars believe the existing law inherently has and secondly, but more importantly, the transformation of the legal thinking of those engaged with its interpretation and application, as called for by Klare. This transformative obligation can be directly transplanted to the interpretation and application of consumer law.

126 Idem par 23

127 Idem parr $36 \& 24$

128 Idem par 24.

129 Klare 1998 SAJHR 146154

130 Idem 153

131 See Klare 1998 SAJHR 146155 \& 179-180.

132 Everfresh case par 25.

133 Klare 'Concluding reflections: Legal activism after poverty has been declared unconstitutional' in Liebenberg $\&$ Quinot (eds) Law and Poverty: Perspectives form South Africa and Beyond (2012) 423. 


\section{The Law of Contract, Poverty and Distribution}

Davis argues that if the reconfiguration of the background rules of the common law contract is not achieved, the role contract law has to play in the eradication of poverty will never be realised, ${ }^{134}$ since "the law reproduces patterns of power and distribution that reproduce poverty". 135 He equates poverty to inequality and powerlessness ${ }^{136}$ and directly links it to an infringement of the constitutional rights to dignity and freedom. ${ }^{137}$

If "the median person in the developing world, the peripheral contracting party, is rarely skilled, knowledgeable, well-educated or wealthy", 138 this should be considered crucial when equity and contract are analysed. Along the same vein, Barnard contends that our legal system would have differed vastly had "its basic doctrines ... been written by poor people, women and black people". ${ }^{39}$ These basic doctrines refer to the same fundamental legal concepts as Davis' background rules of the law. Barnard further explains these doctrines and rules as "seemingly "value-neutral", 140 which is a dangerous assumption in light of South Africa's transformative project. Judicial decisions illustrate their inherent power to lobby for and achieve justice. ${ }^{141}$ But social justice is incompatible with a strictly liberal manner of interpreting and enforcing contracts, as this approach rejects "the general fairness criterion" and the result is the denial of equity and human dignity as entrenched in the Bill of Rights. ${ }^{142}$

Barnard argues that the normative values of the Constitution and the interdependent nature of a community, creates the obligation to contract in an ethical manner. ${ }^{143}$ For Barnard contractual justice entails each individual taking responsibility for the advancement of her own needs and welfare as well as those of the other members of the community, who are in turn potential contracting parties. ${ }^{144}$ This therefore, strengthens the notion that contractual justice can be achieved by means of a lived experience of ubuntu.

Economic marginalisation is as serious and unjust as is discrimination based on race, gender or disability, and these forms of social injustice

134 Davis 2011 Stell LR 845857

135 Idem 860 (own emphasis).

136 Idem 862.

137 Idem 863. In this regard also see Barnard AJ 231-232.

138 Hawthorne 2006 THRHR 48 61-62 (own emphasis). The CPA refers to these individuals as vulnerable consumers, those who deserve the most protection in terms of the application and interpretation of the Act ( $\mathrm{s}$ 3(1)(b)).

139 Barnard AJ 212

140 Idem 220

141 Klare 1998 SAJHR 146147.

142 Barnard AJ 221-222.

143 Idem 212.

144 Idem 243 
reinforce each other to create an unavoidable sequence of economic and cultural suppression. ${ }^{145}$ This again highlights the importance of the right to human dignity, which has been linked to the manner in which individuals contract with one another.

Hawthorne supports this theory. Where commodities and property trade hands, these distributive agreements facilitate the distribution of wealth. ${ }^{146}$ The fact that the contracts that distribute wealth are often concluded and enforced in an unconscionable fashion, creates severe injustices in our society and, in a socio-political climate where mass service delivery protests are the order of the day, it would be unwise to continue ignoring these injustices.

The traditional notion that neither judicial decision-making nor legislation should interfere with the almost religiously defended notion of the freedom of contract, results in the reproduction of social inequalities and the domination and exploitation of one contracting party over another. This view that contracts play no role in the socio-economic and political sphere of society leaves no room for the acknowledgement of the importance of the distribution of wealth. Such disregard would imply that protecting the most vulnerable members of society (who are automatically the weakest role-players in the economic market) from the effects of poverty is of no importance, and this view cannot be supported in light of South Africa's constitutional dispensation and disparate socioeconomic situation. The consumer contract's potential impact on poverty in South Africa, illustrates the reason legislative intervention was required in this area of the law. As social justice legislation, the CPA shines the spotlight on the importance of addressing poverty in South Africa. The fundamental consumer rights protected by the Act ${ }^{147}$ provide the roadmap for achieving ethical contracting in consumer agreements.

\section{The Consumer Protection Act as Transformation}

Consumer legislation has introduced various measures to infuse fairness and conscionability into the law of purchase and sale. But, as Davis argues, the fairness envisaged will only be achieved if the general law of contract is applied in an ethical manner. Striving towards such an ethical

145 Fraser 'From redistribution to recognition? Dilemmas of justice in a "postsocialist age"' in Olson (ed) Adding Insult to Injury: Nancy Fraser Debates her Critics (2008) 16, as quoted by Liebenberg Socio-economic Rights Adjudication under a Transformative Constitution (2010) 481.

146 Hawthorne 2006 THRHR 48 56. In this regard also see Davis 2011 Stell LR 845 848-849 referring to Hale 'Coercion and Distribution in a Supposedly Non Coercive State' 192338 Political Science Quarterly 470 472-473, where the hypothetical position of the hungry (wo)man, forced to contract, is discussed: If she does not accept the contractual terms imposed by the other party she will starve.

147 See ch 2 parts A-H in this regard. 
utopia also requires that the lived realities of the contracting parties be considered in order to bridge the chasm caused by unequal bargaining power.

Section 7 of the Constitution compels the state to actively protect and promote the rights enshrined in the Bill of Rights. By enacting the CPA, the state has provided legal practitioners, the judiciary and academics the tools with which to promote and advance constitutionally guided transformation of the South African common law of contract.

Legislation is often drafted to give light to public policy and the boni mores. ${ }^{148}$ The CPA is an excellent example of such legislation. ${ }^{149}$ The Act follows a rights-based approach, structuring the protection granted to consumers in terms of specific rights. ${ }^{150}$ The Act provides a broad spectrum of justifications for its enactment. ${ }^{151}$ These are found in the long title, preamble and Part B of Chapter 1 of the Act, which provides the purpose of the legislation. The golden thread running through these, is the aim of promoting and advancing "the social and economic welfare of consumers in South Africa" ${ }^{152}$ This broader aim of the CPA relates to the transformative goals of the Constitution and the desire to bring about social and economic transformation across the greater South African society. Section 4(2)(b)(i) of the CPA expressly states that the Act must be interpreted so as to protect the most vulnerable of consumers in our socio-economic community. These vulnerable persons include poor individuals, those who live in remote communities, minors, seniors, those with no or poor literacy and those with impaired visual functionality. ${ }^{153}$

The CPA's development of the common law on the purchase of defective goods may be analysed as an anecdotal example of the transformation and development introduced by the Act. ${ }^{154} \mathrm{Part} \mathrm{H}$ of Chapter 2 of the Act applies in instances where defective goods ${ }^{155}$ have

148 Du Plessis The unilateral determination of price in contracts of sale governed by the Consumer Protection Act 68 of 2008 (LLM dissertation 2012 UP) 91.

149 Woker 2010 Obiter 217230.

150 Meiring 'Consequences of non-compliance with the Consumer Protection Act 68 of 2008' 2010 Without Prejudice 28.

151 See ss $3 \& 4$ of the CPA in this regard.

152 S 3(1)

153 S 3(1)(b).

154 An in-depth evaluation of the law on defective goods falls beyond the scope of this article. The developed position discussed here merely provides a glimpse into the transformative power of in the CPA.

155 When reading s 55(5)(a) together with s 53, it becomes evident that the nature of the defect present in the goods is irrelevant; "any" defect is taken into consideration, be it latent or patent (ss 53(1)(a)(i)-(ii)). Barnard argues that s 53 of the Act confirms the common law definition of a latent defect (as provided in Holmdene Brickworks (Pty) Ltd $v$ Roberts Construction Co Ltd 19773 SA 670 (A)), but that the Act also extends the scope thereof (Barnard $\mathrm{J}$ (The influence of the Consumer Protection Act 68 of 2008 on the common law of sale (LLD dissertation 2013 UP) 383 455). This means that the consumer is awarded much greater protection under the CPA than under the undeveloped common law on latent defects. 
been sold to the consumer. It is contended that protecting the consumer against the potentially unscrupulous action suppliers could take when selling (defective) goods, may be viewed as a prime example of the type of protection granted to the consumer under the CPA. ${ }^{156}$ When determining whether a consumer's right to safe and good quality goods has been respected, a number of factors are taken into account. ${ }^{157}$ of great importance, is the fact that the court may consider the circumstances surrounding the supply of the goods. ${ }^{158}$ The Act therefore sanctions going beyond the confines of the consumer agreement itself.

The Constitutional Court has started to take relevant social and historical contexts into account "as sources of legal knowledge". ${ }^{159}$ The "abstract considerations subjacent to our law of contract" should be considered as crucial. ${ }^{160}$ The courts therefore, have the responsibility to take cognisance of extra-legal information, but this has, however, not yet been the case in the adjudication of matters of a contractual nature. If section 55(4) of the CPA is scrutinised, it seems as if consumer law might be moving in this direction. Here the Act does not refer to the socioeconomic situations of the parties, ${ }^{161}$ but rather the circumstances surrounding the supply of the goods in question. This includes how and for which purported purpose the goods were marketed, packaged and displayed; whether any trademark, description, instructions or warnings related to the goods were provided; or the reasonable scope of use for which the goods might possibly be employed, at the time when the goods were produced and supplied. ${ }^{162}$ This section clearly broadens the common law idea of the information which may be brought before the courts when deciding matters on defective goods and it therefore encompasses a transformed notion of equity.

156 It should be mentioned that the CPA justifiably limits the liability of the supplier under ss 55(2)(a)-(b) where goods are received by the consumer in a specifically stated condition, and the consumer expressly states that she accepts the goods in the condition in which it has been supplied (s 55(6)(a)). S 55(6)(b), however, states that the liability of the supplier is also limited where the goods in question are supplied in a specifically stated condition, and the consumer "has knowingly acted in a manner consistent with accepting the goods in that condition." This subsection seems to favour the supplier, but since the burden of proof lies with the supplier, and it might be difficult to prove such actions, the supplier might still be held liable. We therefore argue that this subsection creates a justifiable limitation of the supplier's liability, as disputes will be assessed casuistically and where there is any doubt as to the intent of the parties, the consumer will benefit as a result thereof, since the Act will be interpreted in line with its purpose (ss 2-3)

157 See s 55(2) of the Act in this regard.

158 Ss 55(2)(c) \& 55(4)

159 Davis \& Klare 2010 SAJHR 403 495-496 (own emphasis).

160 Barnard 2006 Stell LR 386394.

161 This is done in s 3 of the CPA which states its purpose.

162 Barnard J (supra n 155 at 383-384) provides a detailed discussion of the effect of regulations 44(3)(i)-(j) of the CPA and how these forbid a supplier from unilaterally altering the nature or characteristics of the goods agreed upon. See also s 4(4)(b). 
The CPA also highlights the cardinal importance of addressing and transforming the areas of the common law that ought to provide a measure of fairness in order to protect the consumer. ${ }^{163}$ The transformation implemented by the CPA may therefore, be viewed as an example of the transformation required in the related common law, which applies in instances where the CPA does not. In this regard, the validity of the voetstoots clause ${ }^{164}$ may be mentioned as an example.

Though various conflicting opinions on the matter exist, we agree with Barnard that the voetstoots clause should not be permitted in consumer agreements and transactions as regulated by the CPA. ${ }^{165}$ This interpretation provides the vulnerable consumer with the best protection in instances where defective goods are supplied. This would mean a development of the common law which brings it in line with the constitutionally transformative program. This argument could, however, be taken a step further. If the common law, which applies alongside the CPA in consumer agreements, is developed to deny the application of this waiver of consumer rights, surely this development should be transplanted to the common law which applies to commercial transactions where the CPA is not applicable? This would result in the protection granted to the consumer in terms of a consumer agreement, extending to sales agreements regulated by the common law, ultimately providing the common law purchaser with a more equitable remedy. This would satisfy the duty to transform the common law imposed by section 39(2) of the Constitution and section 4(2)(a) of the CPA.

Section 56(4) dictates that the legislative warranty of quality ${ }^{166}$ applies "in addition to any other implied warranty or condition imposed by the common law, the Act itself, any public regulation or express contractual warranty or condition". Section 2(10) of the Act holds that the consumer may not be denied the exercise of any right she has under the common law, and Barnard correctly argues that, by extension, this includes the common law remedies associated with those rights. ${ }^{167}$ By allowing the common law and consumer legislation to apply at the same time, the legislature has granted the consumer the widest scope of protection available.

The role of consumer legislation, as it attempts to protect the consumer from the economic effects of unfair consumer agreements, should therefore, be considered in conjunction with the constitutionally

$163 \mathrm{~S} \mathrm{4(2)(a).} \mathrm{This} \mathrm{reminds} \mathrm{of} \mathrm{the} \mathrm{similar} \mathrm{responsibility} \mathrm{imposed} \mathrm{by} \mathrm{s} \mathrm{39(2)} \mathrm{of}$ the Constitution.

164 The voetstoots clause is an optional clause which may (at the parties' discretion) be inserted into a contract of sale and has the effect of excluding all liability on the part of the seller for latent defects in the property purchased (Otto 2011 THRHR 525 530).

165 Barnard J (supra n 155) $395 \& 470$.

166 This warranty is specifically created in the Act as a remedy related to the consumer's right to safe, good quality goods as encompassed in s 55 of the Act.

167 Barnard J (supra n 155) 467. 
imposed duty to continually evaluate the fairness and legitimacy of laws, and subsequently also the common law of contract.

\section{Conclusion}

All market transactions that contribute to the system of production create power relations. From the most basic consumer purchase and sale agreement opportunities for the exercise of power present themselves, for instance where a retailer has contracted out of repairing or replacing defective goods, leaving the consumer in a weaker position. ${ }^{168}$

In the not so distant past, judges stated that they were unsure as to whether the common law or the Constitution should guide their interpretation of legislation, ${ }^{169}$ and one could predict that this confusion will most probably reign in future interpretations of consumer legislation in South Africa. However, in light of the importance and prominence of the Constitution's transformative project, the hope is that this uncertainty will soon be a thing of the past; the optimistic expectation being that the normative values of the Constitution will enjoy favour.

The complex issues related to law's true power to change society, provokes the question of whether developments of the consumer law, and related common law, will effectively impact poverty in South Africa. We do, however, conclude that the law's role in transforming South Africa's society cannot be denied. If transformation and development is not strived for, it will never be attained. For true transformation to take place in South Africa, it must be accepted as a national project as well as a challenge to be embraced by all in the community. ${ }^{170}$ How else will we reach the point where we contract in good faith, taking the needs and human dignity of the other contracting party into consideration? Due to its importance and prevalence, the consumer agreement, in terms of which goods are purchased, might be a means to introduce members of the community to a more ethical manner to transact with each other in the marketplace. The boni mores demands that where a consumer (in terms of a consumer agreement) or a purchaser (in terms of a sales agreement which is not governed by the CPA) purchases a defective product from a supplier, the supplier must be held liable for such a defect.

It is blatantly clear that the background legal rules of the law of contract enforce and enshrine the unequal bargaining position, ${ }^{171}$ which originally created the immeasurable inequality in South Africa's, now democratic, society. South African courts need to take responsibility for the fact that their lack of action in this regard is perpetuating the injustices running rampant in South Africa's society. The principles and

168 Hawthorne 2006 THRHR 4857.

169 Van der Walt 2006 Fundamina 1 11-12.

170 In this regard see Smith \& Bauling 'Aiming for transformation: Exploring graduateness in South Africa' 2013 Stell LR 601 603-604.

171 Davis 2011 Stell LR 845849 
aim of the CPA (as constitutionally mandated social justice legislation) could guide judges in their interpretation of the common law of sale. In a country as economically divided as South Africa, incremental changes to the common law of contract has not been sufficient to bring about adequate transformation; one-on-one contractual bouts between parties will not facilitate society-wide transformation:

A legal system based exclusively on individual common law action by "consumer" against "trader", bears no relation to an efficient and fair market characterised by globalisation. Consequently, private contract law has been supplemented and supplanted by statutes, regulations and the introduction of consumer organisations. ${ }^{172}$

The importance of the enactment of the CPA cannot be denied. Hopefully its enactment heralds the era of the ethical contract. Freedom of contract, as imposed by the common law, is reined in by the CPA in a manner that is justified by the socio-economic reality of South Africa's society. Possibly the most valuable contribution made by the CPA is the fact that it broadens the scope of information a court, tribunal or mediator may consider when deciding on a matter, and here the socioeconomic realities of consumers and the level of their individual vulnerabilities are pushed to the fore. This acknowledges the poverty created and perpetuated by unequal bargaining positions and formal equality imposed by the common law of contract. The ideal is that this knowledge will lead to positive action which will contribute to the effort to eradicate poverty in South Africa.

172 Hawthorne 2007 SAPR/PL 477. 